\title{
POLITYKA SPÓJNOŚCI NA RZECZ OCHRONY ZDROWIA A PROBLEM NIERÓWNOŚCI W ZDROWIU W POLSCE - UJĘCIE REGIONALNE
}

\begin{abstract}
Streszczenie
W niniejszym opracowaniu została podjęta próba zidentyfikowania trendów w zakresie nierówności terytorialnych (na poziomie NUTS 2), dotyczących stanu zdrowia w Polsce w odniesieniu do polityki spójności i jej głównych instrumentów. Ze względu na dominująca pozycję regionów jako podmiotów polityki gospodarczej, badania regionalne wydają się szczególnie istotne. Do oceny istniejących tendencji terytorialnego zróżnicowania stanu zdrowia została zastosowana analiza konwergencji. Jak wynika z przeprowadzonych analiz, nadal nie występuje międzywojewódzka konwergencja przeciętnego trwania życia. Obserwowany jest proces dywergencji oczekiwanej długości życia kobiet i mężczyzn niezależnie od miejsca zamieszkania (ogółem) oraz kobiet i mężczyzn w miastach, wskazujący na pogłębiające się nierówności pomiędzy województwami. Regionalne zróżnicowanie trwania życia na wsiach na przestrzeni lat 1995-2013 nie uległo zasadniczym zmianom - nie można wykazać występowania sigma-konwergencji. Nie można także wnioskować o sigma-dywergencji. Uzyskane wyniki nie pozwalają na jednoznaczną ocenę skuteczności polityki spójności w tym zakresie. Pogłębione badania wymagają analiz innych wskaźników stanu zdrowia, zwłaszcza obserwacji trendów umieralności.
\end{abstract}

Słowa kluczowe: nierówności w zdrowiu, polityka spójności, analiza konwergencji, oczekiwana długość życia

\section{COHESION POLICY FOR HEALTH PROTECTION AND HEALTH INEQUALITIES: A REGIONAL APPROACH}

\section{Summary}

The paper is an attempt to identify trends in territorial health inequalities (at NUTS 2 level) in Poland in the context of cohesion policy and its main instruments. The research tool used is convergence analysis. Because regions play a central role in economic policy, regional research seems particularly significant. The conducted analysis has shown that no interregional convergence with regard to average life expectancy has been observed as yet. The life expectancy of males and females diverges regardless of their place of residence (in total), as does the life expectancy of males and females living in urban areas, which points to increasing inequalities among voivodeships. In rural areas, regional differences in life expectancy did not change significantly between 1995 and 2013 - sigma-convergence cannot be detected. No evidence of sigma-divergence has been obtained, either. The results do not allow for an unambiguous 
evaluation of how effective cohesion policies pursued in this area have been. An in-depth investigation would require analyses of other health indicators, particularly mortality rates.

Key words: health inequalities, cohesion policy, convergence analysis, life expectancy

JEL: A13, B23, D63, H51, I14

\section{Wstęp}

Wspieranie działań prowadzących do ograniczenia nierówności gospodarczych, społecznych i terytorialnych w zjednoczonej Europie stanowi główny cel polityki spójności Unii Europejskiej, realizowanej przy użyciu znacznych środków. W wymiarze terytorialnym wiodącym zadaniem jest zmniejszenie różnic pomiędzy krajami członkowskimi (spójność zewnętrzna) i pomiędzy regionami wewnątrz nich (spójność wewnętrzna).

Do czynników warunkujących rozwój regionalny i konkurencyjność jest zaliczany dobrostan zdrowotny, traktowany jako integralna część szeroko rozumianego kapitału ludzkiego [Laskowska, 2012, s. 196-205]. W dobie szybko postępującego procesu starzenia się polskiego społeczeństwa troska o spójność terytorialną wymaga, by ogólnej poprawie stanu zdrowia towarzyszyło zmniejszenie jego regionalnych dysproporcji. W redukcji nierówności w zdrowiu pokłada się nadzieję na spadek skali ubóstwa [Policy paper dla ochrony zdrowia..., 2014, s. 3].

Od kiedy Polska stała się beneficjentem polityki spójności, korzysta ze środków pochodzących z funduszy strukturalnych i inwestycyjnych przeznaczonych na interwencje $\mathrm{w}$ dziedzinie ochrony zdrowia. Fundusze unijne, które odgrywają istotną rolę w finansowaniu inwestycji w tym sektorze [Zarys sytemu ochrony zdrowia..., 2012 s. 109], powinny m.in. prowadzić do zmniejszenia nierówności w zdrowiu w wymiarze terytorialnym, będącym jedną z głównych zasad ich podziału. Powstaje pytanie, czy fundusze przeznaczane na ochronę zdrowia w ramach polityki spójności są skuteczne, tzn. czy przyczyniają się do zmniejszenia nierówności w zdrowiu? Adekwatne do potrzeb zdrowotnych wykorzystanie funduszy europejskich stwarza szanse na równomierny rozwój kapitału ludzkiego w polskich regionach [Przestrzenny mymiar nierónności..., 2011, s. 38].

W niniejszym opracowaniu została podjęta próba zidentyfikowania trendów w zakresie nierówności terytorialnych (na poziomie NUTS 2), dotyczących stanu zdrowia w Polsce, w odniesieniu do polityki spójności i jej głównych instrumentów. Ze względu na dominująca pozycję regionów jako podmiotów polityki gospodarczej, badania regionalne wydają się szczególnie istotne. Wymiar ten jest ważny z racji planowania infrastruktury ochrony zdrowia.

Do oceny istniejących tendencji terytorialnego zróżnicowania stanu zdrowia została zastosowana analiza konwergencji ${ }^{1}$. Ożywiona dyskusja w literaturze ekonomicznej

\footnotetext{
$1 \mathrm{~W}$ badaniach nad zjawiskiem konwergencji pojęciowo rozróżnia się konwergencję wewnętrzna (wewnątrzkrajowa) i konwergencję zewnętrzną (międzykrajowa). Stanowiąca przedmiot rozważań zawartych w niniejszym artykule konwergencja wewnętrzna może dotyczyć jednostek statystycznych NUTS 2 i NUTS 3 [Kusideł, 2013, s. 39].
} 
na temat procesu konwergencji gospodarczej [Barro, Sala-I-Martin, 1991; Kusideł, 2013] spowodowała wzrost zainteresowania metodologia jej pomiaru w wielu innych płaszczyznach życia. Rośnie liczba badań empirycznych prowadzonych na świecie w dziedzinie ochrony zdrowia, poruszających problematykę konwergencji wybranych wskaźników stanu zdrowia [Goli, Arokiasamy, 2014; Gächter, Theurl, 2011; Mackenbach, 2013; Janssen, van den Hende, de Beer, van Wissen, 2016; Liang, Zhang, Huang, Schweitzer, 2016].

W artykule zawarto analizy skoncentrowane na regionalnym (międzywojewódzkim) zróżnicowaniu oczekiwanej długości życia w momencie narodzin z podziałem na płeć i z uwzględnieniem miejsca zamieszkania (miasto - wieś). Badania konwergencji objęły lata 1995-2013. Dolny zakres czasowy jest najwcześniejszym okresem, dla którego można było prowadzić w Polsce badania dla podziału wojewódzkiego zgodnego z europejską klasyfikacją NUTS 2. Rok końcowy był ostatnim w perspektywie finansowej 2007-2013. W analizie wyodrębniono podokres zapoczątkowany wstąpieniem Polski w struktury Unii Europejskiej (2004-2013).

\section{Fundusze europejskie dla sektora ochrony zdrowia i stan zdrowia w perspektywie regionalnej}

Unia Europejska wspiera inwestycje w dziedzinie zdrowia publicznego i opieki zdrowotnej dzięki europejskim funduszom strukturalnym i inwestycyjnym. Polityka spójności przede wszystkim jest realizowana dzięki dwom funduszom strukturalnym, a mianowicie: Europejskiemu Funduszowi Rozwoju Regionalnego (EFRR) oraz Europejskiemu Funduszowi Społecznemu (EFS), stanowiącym instrumenty realizacji Narodowej Strategii Spójności. Europejski Fundusz Społeczny, z którego środków finansowych Polska korzysta od 2007 roku, jest podstawowym źródłem dofinansowania procesu podnoszenia kwalifikacji przez pracowników sektora ochrony zdrowia. Szczególną rolę we wzmocnieniu spójności gospodarczej i społecznej, przy jednoczesnym zmniejszeniu dysproporcji regionalnych, odgrywa Europejski Fundusz Rozwoju Regionalnego. Realizacja inwestycji finansowanych z tego funduszu nastapiła już w latach 2004-2006, a jednym $z$ celów dofinansowania było ograniczenie regionalnych dysproporcji w infrastrukturze zdrowotnej [Dubas-Jakóbczyk, 2014]. Fundusze unijne dla sektora ochrony zdrowia, przypadające na ten okres, objęły zaledwie $10 \%$ wszystkich środków otrzymanych w latach 2004-2013. Najwyższe wsparcie z Europejskiego Funduszu Rozwoju Regionalnego miało miejsce w latach 2007-2013, zdecydowanie przewyższając środki pochodzące z Europejskiego Funduszu Społecznego w tym samym okresie programowania (wykres 1.). 
WYKRES 1. Struktura liczby podpisanych umów i wartości dofinansowań w ramach EFS i EFRR, w okresie 2007-2013²

\section{Liczba podpisanych umów}

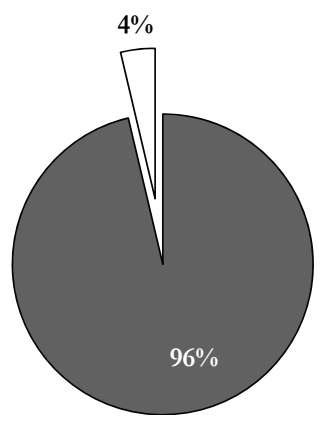

Wartość dofinansowania dla sektora ochrony zdrowia

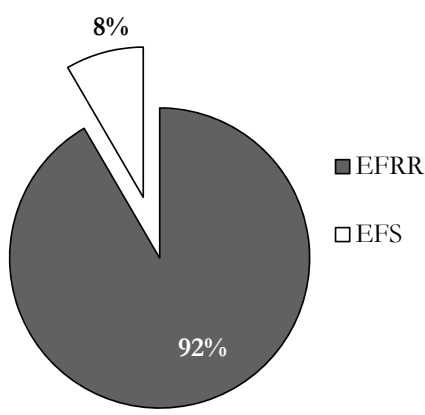

Źródło: opracowanie własne na podstawie: [Mapa Dotacji UE].

W okresie programowania 2007-2013 podstawowe źródła finansowania inwestycji infrastrukturalnych w ochronie zdrowia stanowiły: Program Operacyjny Infrastruktura i Środowisko oraz regionalne programy operacyjne poszczególnych województw. W Programie Operacyjnym Infrastruktura i Środowisko wsparcie dla ochrony zdrowia zostało przewidziane w ramach priorytetu: „Bezpieczeństwo zdrowotne i poprawa efektywności systemu ochrony zdrowia", którego celem ogólnym było wspieranie utrzymania dobrego poziomu zdrowia zasobów pracy. Natomiast regionalne programy operacyjne, opracowywane indywidualnie przez władze każdego województwa, pozwalały na wybór odmiennych priorytetów w ramach programów różnych województw [Dubas-Jakóbczyk, 2014, s. 231].

Zasadniczym celem funduszy skierowanych do systemu ochrony zdrowia jest m.in. poprawa stanu zdrowia obywateli, prowadząca do wzrostu liczby osób aktywnych zawodowo [Mazurek, 2010, s. 577]. Wśród celów szczegółowych można wymienić: poprawę jakości usług medycznych świadczonych przez wysokospecjalistyczne zakłady opieki zdrowotnej, ograniczenie regionalnych dysproporcji w infrastrukturze zdrowotnej, poprawę jakości i dostępności do systemu ratownictwa medycznego, poprawę jakości lecznictwa specjalistycznego i wysokospecjalistycznego, zarówno stacjonarnego, jak i ambulatoryjnego [Departament Fundussy Europejskich Ministerstwa Zdrowia]. Wprawdzie, jak wynika z szeregu koncepcji porządkujących czynniki warunkujące stan zdrowia, z których obecnie najbardziej wpływową jest model G. Dahlgrena i M. Whiteheada [Dahlgren, Whitehead, 2007, s. 20], opieka zdrowotna jest tylko jednym z nich, lecz brak dostępu do świadczeń zdrowotnych niejednokrotnie może stanowić o zagrożeniu zdrowia i życia [Præestrženny mymiar nierówności..., 2011, s. 38]. Nierówności statusu zdrowotnego

\footnotetext{
${ }^{2}$ Udziały zostały wyznaczone na podstawie sumy dofinansowań Unii Europejskiej w ramach poszczególnych funduszy, tzn. EFS i EFR, dla wszystkich województw.
} 
w znacznej mierze są pochodną nierówności w dostępie do odpowiedniej jakości świadczeń. Ocena skuteczności działań podjętych na rzecz poprawy kondycji zdrowotnej wymaga systematycznego monitorowania zmian kluczowych indykatorów stanu zdrowia. Za jeden z obiektywnych mierników kondycji zdrowotnej i podstawę wielu analiz nierówności w zdrowiu uznaje się długość trwania życia [Przestrzenny wymiar nierówności..., 2011, s. 39].

W okresie finansowania 2007-2013 z Europejskiego Funduszu Rozwoju Regionalnego na ochronę zdrowia w Polsce przeznaczono $613843850 \mathrm{mln}$ euro. Alokację środków z tego okresu programowania w podziale na województwa w zestawieniu z przestrzennym zróżnicowaniem oczekiwanej długości życia i jej zmian w okresie objętym oddziaływaniem polityki spójności obrazuje tabela 1.

TABELA 1.

Alokacja środków wspólnotowych z EFRR dla sektora ochrony zdrowia oraz oczekiwana długość życia i jej zmiany według województw

\begin{tabular}{|c|c|c|c|c|c|c|}
\hline \multirow[t]{3}{*}{ Województwo } & \multirow{2}{*}{\multicolumn{2}{|c|}{$\begin{array}{l}\text { Środki z EFRR na och- } \\
\text { ronę zdrowia w okresie } \\
2007-2013 \text { (w euro) }\end{array}$}} & \multicolumn{4}{|c|}{$\begin{array}{c}\text { Oczekiwana długość życia w momencie } \\
\text { narodzin }\end{array}$} \\
\hline & & & \multicolumn{2}{|c|}{ kobiety } & \multicolumn{2}{|c|}{ mężczyźni } \\
\hline & ogółem & $\begin{array}{l}\text { na miesz- } \\
\text { kańca }\end{array}$ & 2013 & $\begin{array}{c}\text { przyrost } \\
\text { w okresie } \\
2004-2013 \\
\text { (lata) }\end{array}$ & 2013 & $\begin{array}{c}\text { przyrost } \\
\text { w okresie } \\
2004-2013 \\
\text { (lata) }\end{array}$ \\
\hline świętokrzyskie & 50806509 & 40,22 & 81,5 & 1,2 & 72,8 & 1,9 \\
\hline lubelskie & 53460000 & 24,89 & 81,6 & 2,1 & 72,7 & 2,7 \\
\hline warmińsko-mazurskie & 35096261 & 24,31 & 80,8 & 1,7 & 71,9 & 2,2 \\
\hline zachodniopomorskie & 36810000 & 21,46 & 80,5 & 2,0 & 72,7 & 2,4 \\
\hline kujawsko-pomorskie & 42333938 & 20,26 & 80,5 & 1,8 & 72,9 & 2,3 \\
\hline podkarpackie & 39543512 & 18,57 & 82,4 & 2,2 & 74,8 & 3,0 \\
\hline dolnośląskie & 52722970 & 18,13 & 80,9 & 2,3 & 72,5 & 2,4 \\
\hline łódzkie & 41060341 & 16,40 & 80,1 & 1,6 & 70,7 & 1,6 \\
\hline podlaskie & 19000000 & 15,94 & 82,3 & 2,2 & 73,2 & 2,0 \\
\hline pomorskie & 35402630 & 15,38 & 81,2 & 1,8 & 74,1 & 2,7 \\
\hline wielkopolskie & 52620000 & 15,15 & 80,6 & 1,7 & 73,5 & 2,7 \\
\hline lubuskie & 13172194 & 12,91 & 80,1 & 1,5 & 72,2 & 2,1 \\
\hline opolskie & 12814344 & 12,80 & 80,9 & 1,2 & 73,5 & 1,6 \\
\hline mazowieckie & 61240953 & 11,48 & 81,6 & 1,7 & 73,4 & 2,4 \\
\hline małopolskie & 30001198 & 8,91 & 82,0 & 1,7 & 74,8 & 2,8 \\
\hline śląskie & 37759000 & 8,23 & 80,1 & 1,7 & 72,4 & 2,2 \\
\hline Polska & 613843850 & 17,81 & 81,1 & 1,9 & 73,1 & 2,4 \\
\hline
\end{tabular}

Uwaga: województwa zostały uporządkowane ze względu na wartość środków z EFRR na mieszkańca (w porządku malejącym).

Źródło: opracowanie własne na podstawie danych Ministerstwa Zdrowia: [Departament Funduszy Europejskich...] i danych GUS [Bank Danych Lokalnych (a)]. 
Najwięcej, co do wartości, ogółem środków unijnych w ramach funduszu EFRR trafiło do województw silnych gospodarczo ze stolicami w dużych aglomeracjach miejskich, a mianowicie: mazowieckiego, dolnośląskiego, wielkopolskiego. Województwo mazowieckie - obok opolskiego i podkarpackiego - należało do województw, w których w okresie objętym polityką spójności nastapiła wyraźna poprawa dostępności lecznictwa szpitalnego, mierzona liczbą ludności przypadającej na jedno łóżko szpitalne w szpitalach ogólnych ${ }^{3}$. W województwie wielkopolskim natomiast dostępność świadczeń mierzona tym wskaźnikiem uległa pogorszeniu. Pokaźne środki zostały również przeznaczone dla województw słabszych gospodarczo, tj. lubelskiego i świętokrzyskiego. W relacji do liczby ludności największymi beneficjentami środków wspólnotowych stały się województwa: świętokrzyskie, lubelskie, warmińsko-mazurskie, zachodniopomorskie i kujawsko-pomorskie. W ujęciu ogólnym, w najmniejszym stopniu z funduszy skorzystały województwa: opolskie, lubuskie, podlaskie. W przeliczeniu na mieszkańca zaś - małopolskie i śląskie. Dostępność świadczeń szpitalnych w 2013 roku w województwach: śląskim, podlaskim i opolskim była niższa niż przed rokiem 2004 [Bank Danych Lokalnych (b)].

Sytuacja zdrowotna, mierzona przeciętnym trwaniem życia w Polsce, ulega systematycznej poprawie, jednak występuje jej wyraźne zróżnicowanie międzywojewódzkie. Od wielu lat najkrócej żyją kobiety i mężczyźni zamieszkujący województwo łódzkie. W podobnej sytuacji są mieszkanki województwa śląskiego. Najwyższa wartość tego wskaźnika dla mężczyzn jest obserwowana w województwach: podkarpackim i małopolskim, dla kobiet - w podkarpackim i podlaskim.

Jak wynika z danych GUS [Bank Danych Lokalnych (c)], na przestrzeni lat 1995-2013 poszczególne województwa cechowała różna dynamika zmian stanu zdrowia. Do najniższych w kraju należał przyrost oczekiwanej długości życia mężczyzn w województwach: świętokrzyskim, śląskim i łódzkim (około 4,5 roku). Najwyraźniejsze zmiany zaszły w województwach: zachodniopomorskim i wielkopolskim (powyżej 6 lat). W analogicznym okresie trwanie życia kobiet w województwach dolnoślasskim i małopolskim uległo wydłużeniu o 5 lat. Niewiele niższy (4,9 roku) przyrost oczekiwanej długości życia nastapił w województwach: pomorskim i mazowieckim. W województwie warmińsko-mazurskim dynamika zmian w latach 1995-2013 była zdecydowanie niższa. Natomiast w podokresie 2004-2013 najbardziej odczuwalne, pozytywne zmiany oczekiwanej długości życia mężczyzn zaobserwowano w województwie podkarpackim, oczekiwanej długości życia kobiet w województwie dolnośląskim. W województwach tych wartość środków pomocowych w przeliczeniu na mieszkańca przekraczała wartość średnią dla Polski, choć nie należała do najwyższych w kraju.

Zróżnicowane tempo zmian (tabela 1.) spowodowało, że ogólnej poprawie stanu zdrowia towarzyszyły narastające nierówności międzywojewódzkie. W 2004 roku, kiedy Polska wstępowała w struktury Unii Europejskiej, we wszystkich polskich województwach oczekiwana długość życia mężczyzn nie przekraczała 72 lat, kobiet - 80,3 lat, a maksymalna różnica pomiędzy województwami wynosiła odpowiednio: 2,9 i 1,9 roku.

\footnotetext{
3 Przy ocenie dostępności świadczeń szpitalnych w poszczególnych województwach należy brać pod uwagę również inne aspekty, np. możliwość wyboru szpitala przez pacjenta czy też wysokospecjalistyczny charakter niektórych placówek [Zdrowie i ochrona zdrowia w 2013 roku, 2014, s. 74].
} 
Z mającym miejsce w okresie 2004-2013 wzrostem oczekiwanej długości życia mieszkańców wszystkich województw wiązał się wzrost nierówności regionalnych. Maksymalna różnica oczekiwanej długości życia pomiędzy województwami w roku 2013 wynosiła około 4 lat dla mężczyzn i 2,3 roku dla kobiet.

Analiza zmian oczekiwanej długości życia w odniesieniu do środków przeznaczonych na ochronę zdrowia w ramach EFRR nie pozwala na sformułowanie jednoznacznych wniosków. Istnieją bowiem województwa o stosunkowo niskim poziomie wsparcia na mieszkańca, w których obserwowane zmiany należą do najbardziej korzystnych w kraju (np. województwo małopolskie z jednym z największych w kraju przyrostem oczekiwanej długości życia mężczyzn), a także takie, w których wysokie dofinansowanie w postaci środków EFRR nie przekłada się na równie wysoki przyrost oczekiwanej długości życia (np.: świętokrzyskie, warmińsko-mazurskie). Można jednak zauważyć pewne prawidłowości: w województwach o niższym dofinansowaniu dla sektora ochrony zdrowia (kwota na mieszkańca poniżej średniej dla Polski) obserwowane zmiany trwania życia kobiet były mniej korzystne niż w pozostałych rejonach. Wyjątek stanowi województwo podlaskie o relatywnie wysokim przyroście oczekiwanej długości życia kobiet.

Na uwagę zasługują utrzymujące się różnice stanu zdrowia w miastach i na obszarach wiejskich. Mieszkanki wsi na ogół żyją krócej niż mieszkanki miast. Również przyrost długości życia kobiet na wsiach w ostatnich latach był niższy niż w miastach. Sytuacja mężczyzn była podobna i niemal we wszystkich województwach mężczyźni mieszkający w miastach żyją przeciętnie dłużej niż mieszkańcy wsi (miasta - 73,5 roku, wieś - 72,4 roku), wyjątek stanowiło województwo śląskie. Ponadto, przyrost oczekiwanej długości życia mężczyzn w miastach był wyższy od obserwowanego na wsiach.

Regionalne zróżnicowanie trwania życia kobiet i mężczyzn w miastach i na wsiach (oś lewa) oraz jego zmian w okresie 2004-2013 (oś prawa) obrazują wykresy: 2. i 3.

Jak wynika z danych GUS, nastąpił wyraźny wzrost zróżnicowania międzywojewódzkiego trwania życia mężczyzn mieszkających w miastach. Maksymalna różnica pomiędzy województwami wynosiła 5,1 roku w 2013 roku, podczas gdy w 2004 roku było to 3,4 roku, a w 1995 roku - 3,6 roku. W stosunku do roku 2004 równocześnie nie uległy redukcji międzywojewódzkie dysproporcje trwania życia mężczyzn na wsiach. W 2013 roku różnica wynosiła 3,6 roku, w 2004 roku - 3,2 roku. Były jednak niższe niż w 1995 roku (4,5 roku).

Jednocześnie wzrosły nierówności w trwaniu życia kobiet niezależnie od miejsca zamieszkania. Dla kobiet w miastach różnica w 2013 roku wynosiła 2,7 roku i przewyższała tę z 2004 roku (2,3 roku) i 1995 roku (2 lata). Dla kobiet na wsiach było to odpowiednio: w 2013 roku - 2,8 roku, wobec 2,4 roku w 2004 roku i 2,9 roku w 1995 roku.

Odmienna sytuacja w miastach i na wsiach - szczególnie mężczyzn - rodzi konieczność prowadzenia dalszych analiz międzywojewódzkiego zróżnicowania trwania życia z uwzględnieniem płci i klasy miejscowości zamieszkania. Na pełną analizę występujących tendencji, umożliwiającą ocenę systematycznych zmian w okresie 1995-2013, pozwala analiza konwergencji ujmująca wszystkie badane okresy. 
WYKRES 2.

Trwanie życia kobiet w miastach i na wsiach w 2013 roku oraz jego przyrost w okresie 2004-2013, według województw

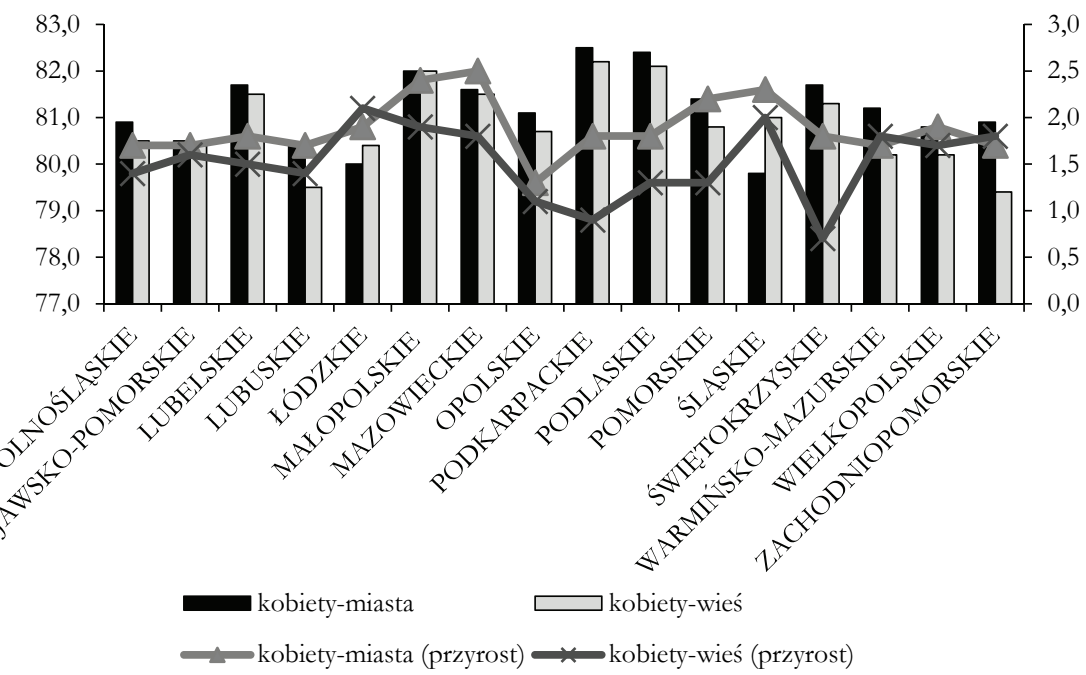

Źródło: opracowanie własne na podstawie danych GUS: [Bank Danych Lokalnych (a)].

WYKRES 3.

Trwanie życia mężczyzn w miastach i na wsiach w 2013 roku oraz jego przyrost w okresie 2004-2013, według województw
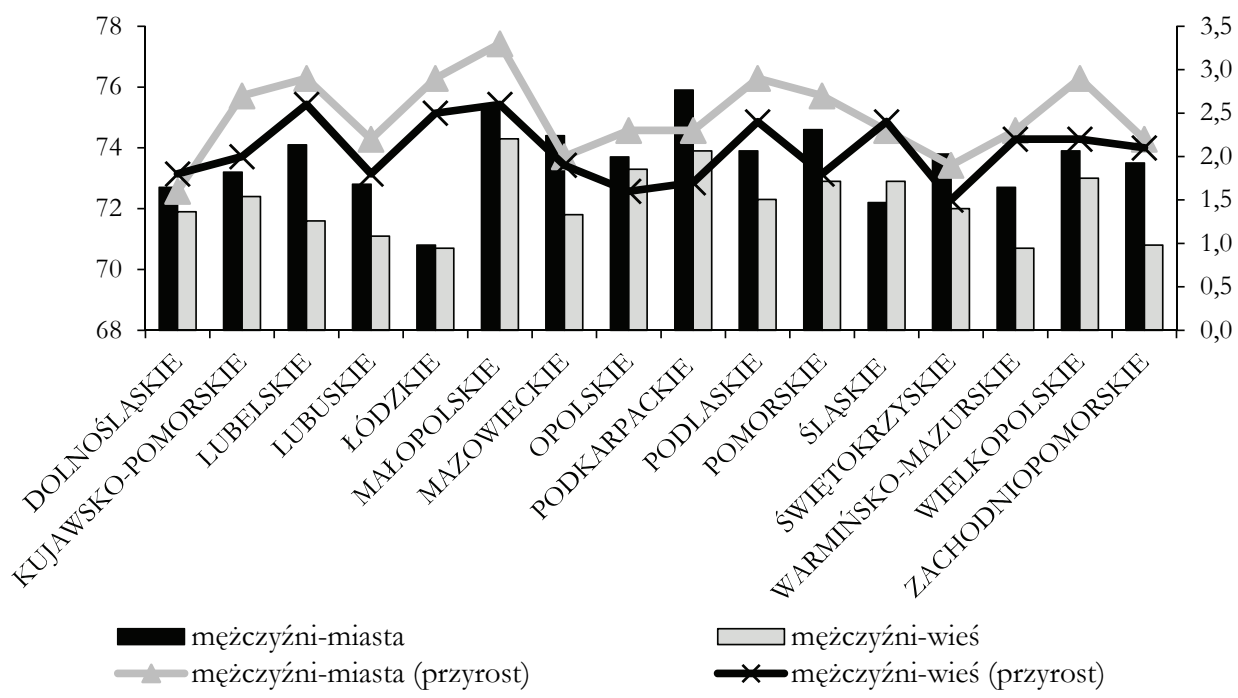

Źródło: opracowanie własne na podstawie danych GUS: [Bank Danych Lokalnych (a)]. 


\section{Konwergencja czy dywergencja oczekiwanej długości życia?}

Zainteresowanie metodologia analizy konwergencji w dziedzinach, takich jak demografia czy zdrowie publiczne wzięło swój początek w literaturze ekonomicznej poświęconej konwergencji dochodowej. Analiza konwergencji umożliwia zbadanie upodabniania się badanych zmiennych (zjawisk) w dwóch ujęciach, określanych mianem sigma-konwergencji i beta-konwergencji. Beta-konwergencja oznacza „doganianie” (catch-up effect), a jej analiza koncentruje się na badaniu zależności między średniookresowym tempem zmian przyjętego miernika a jego wartością początkową w grupie badanych jednostek [Kusideł, 2013, s. 63]. Natomiast konwergencja typu sigma zakłada redukcję nierówności (zmniejszenie dyspersji badanego zjawiska) w czasie. Zachodzenie konwergencji beta stanowi warunek konieczny, lecz niewystarczający do zaistnienia konwergencji sigma [Geodecki, 2006, s. 77], zaś istnienie sigma-konwergencji zjawiska oznacza automatycznie występowanie konwergencji typu beta. Dalsza część opracowania została poświęcona analizie konwergencji wewnętrznej (międzywojewódzkiej) typu sigma oczekiwanej długości życia.

Ocena zbieżności sigma wymaga oszacowania miary nierówności badanego zjawiska wśród analizowanych obszarów w kolejnych okresach analizy. Wybór metodologii pomiaru nasilenia nierówności pozostaje przedmiotem ciagłych rozważań. Jest bowiem wiele sposobów pomiaru różniących się stopniem trudności i stopniem spełnienia układu aksjomatów stawianych przed miarami nierówności [Laskowska, 2012, s. 9091]. W badaniu konwergencji regionalnej oczekiwanej długości życia wykorzystano jedną spośród najczęściej stosowanych statystycznych miar sigma-konwergencji, tj. współczynnik zmienności, pozwalający na uwzględnienie zmian, jakie zaszły we wszystkich analizowanych regionach:

$$
V_{t}=\frac{S_{t}}{\bar{y}_{t}},
$$

gdzie $S_{t}$ jest odchyleniem standardowym badanej zmiennej w okresie (roku) $t, \bar{y}_{t}$ - średnim poziomem zmiennej $y$ (tutaj oczekiwanej długości życia w momencie narodzin) w okresie $t$ dla $i=1, \ldots, N$ obszarów. Spadek nierówności, mierzonej współczynnikiem zmienności, wskazuje na występowanie sigma-konwergencji.

Analiza konwergencji typu sigma może zostać uzupełniona oszacowaniem liniowego modelu trendu dla wartości współczynnika zmienności:

$$
V_{t}=\alpha_{0}+\alpha_{1} t+\xi_{t},
$$

gdzie: $\alpha_{0}, \alpha_{1}$ - parametry strukturalne, $\xi$ - składnik losowy równania, $t-$ zmienna czasowa $(t=1, \ldots, T)$.

O występowaniu konwergencji typu sigma można wnioskować, jeśli parametr $\alpha_{1}$ powyższego równania jest ujemny i istotny statystycznie [Kusideł, 2013].

Wyniki analizy międzywojewódzkiej sigma-konwergencji oczekiwanej długości życia z uwzględnieniem płci i klasy miejscowości przedstawiono na wykresie 4. 
WYKRES 4.

Graficzna prezentacja wyników analizy sigma-konwergencji oczekiwanej długości życia w momencie narodzin, w latach 1995-2013 - wartość współczynnika zmienności

a. Kobiety ogółem

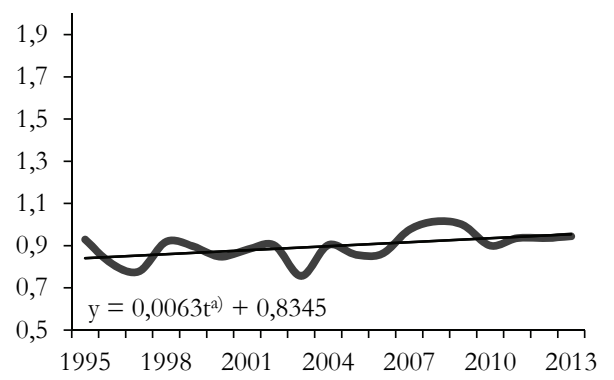

c. Kobiety - miasta

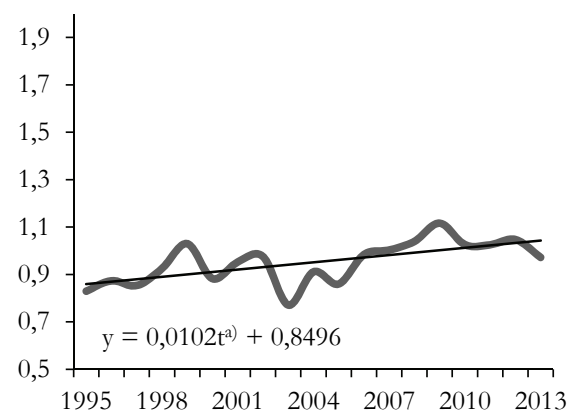

e. Kobiety - wieś

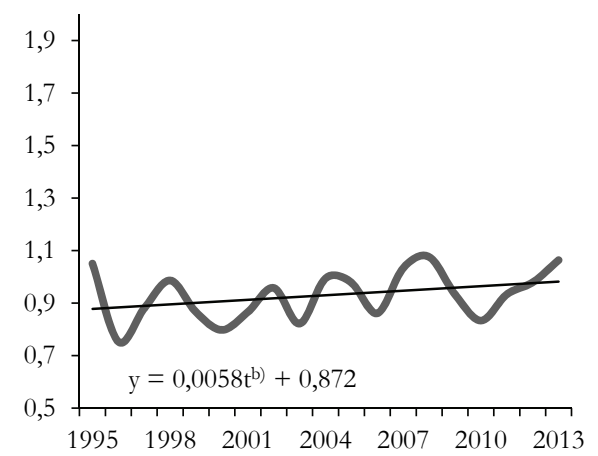

b. Mężczyźni ogółem
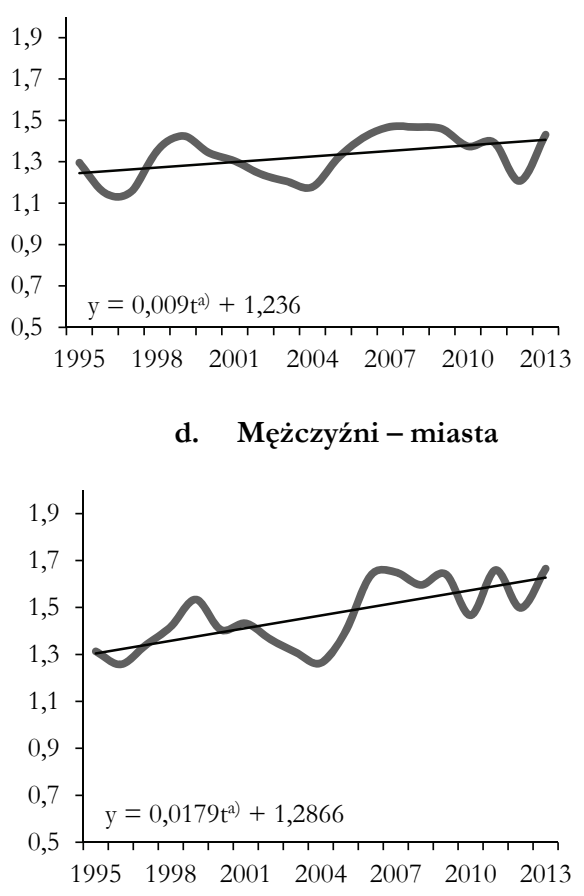

f. Mężczyźni - wieś

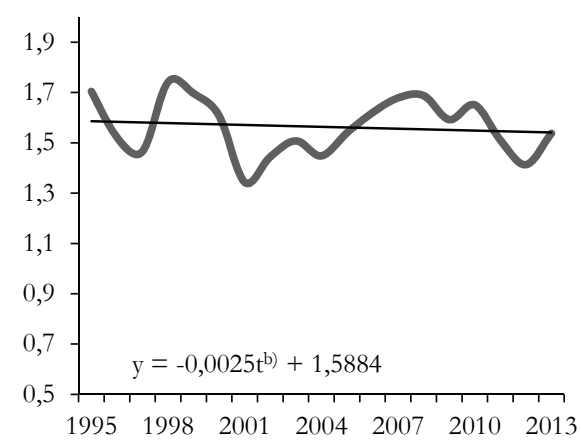

Uwagi: a) parametr statystycznie istotny (dla $\alpha=0.05$ ),

b) parametr statystycznie nieistotny (dla $\alpha=0.05)$.

Źródło: obliczenia własne na podstawie danych GUS [Bank Danych Lokalnych (a)]. 
W odniesieniu do poszczególnych zmiennych analiza konwergencji typu sigma przyniosła zróżnicowane rezultaty. Jak wynika z badań, w całym analizowanym okresie utrzymywało się wyższe międzywojewódzkie zróżnicowanie oczekiwanej długości życia mężczyzn niż kobiet, zarówno w miastach, jak i na wsiach, na co wskazuje wartość współczynnika zmienności.

Po roku 2004 nie zaobserwowano systematycznego spadku nierówności oczekiwanej długości życia, mierzonej współczynnikiem zmienności, dla żadnej z analizowanych kategorii. Stwierdzono pogłębienie różnic w przekroju regionalnym wśród mieszkańców miast (kobiet i mężczyzn).

Nachylenie linii trendu na powyższych wykresach oraz dodatnie znaki ocen parametrów przy zmiennej czasowej $t$ sugerują brak konwergencji regionalnej dla oczekiwanej długości życia mężczyzn i kobiet ogółem oraz mężczyzn i kobiet w miastach. Inaczej jest w przypadku kobiet i mężczyzn na wsiach. Współczynniki przy zmiennej czasowej $t$ w równaniach dla kobiet i mężczyzn na wsi nie są istotne statystycznie, co przekłada się na brak znaczących zmian w zakresie regionalnych nierówności oczekiwanej długości życia mieszkańców i mieszkanek wsi.

\section{Podsumowanie}

Polityka spójności, realizowana w Polsce od początku 2004 roku, stanowi obecnie jedno z największych źródeł służących finansowaniu zmniejszenia dysproporcji w zakresie rozwoju regionów. W jej ramach zostały również przewidziane środki na inwestycje w sektorze ochrony zdrowia prowadzące m.in. do poprawy stanu zdrowia obywateli. W okresie objętym działaniem polityki spójności korzystne zmiany sytuacji zdrowotnej, wyrażonej za pomocą oczekiwanej długości życia, zaszły we wszystkich województwach, przy czym były one wyraźniejsze w miastach niż na wsiach.

Wyzwaniem dla współczesnej polityki zdrowotnej jest poprawa stanu zdrowia, której towarzyszy spadek nierówności zdrowotnych w przekroju społecznym i terytorialnym [Blas, Kurup, 2010; Health inequalities in the EU..., 2013]. Jak wynika z przeprowadzonych analiz, nadal nie ma miejsca międzywojewódzka konwergencja przeciętnego trwania życia. Obserwowany jest proces dywergencji oczekiwanej długości życia kobiet i mężczyzn niezależnie od miejsca zamieszkania (ogółem) oraz kobiet i mężczyzn w miastach, wskazujący na pogłębiające się nierówności pomiędzy województwami. Regionalne zróżnicowanie trwania życia na wsiach na przestrzeni lat 1995-2013 nie uległo zasadniczym zmianom - nie można wykazać występowania konwergencji typu sigma. Nie można także wnioskować o sigma dywergencji. Uzyskane wyniki nie pozwalają na jednoznaczną ocenę skuteczności polityki spójności w tym zakresie. Pogłębione badania wymagają analiz innych wskaźników stanu zdrowia, zwłaszcza obserwacji trendów umieralności.

Rozważania przedstawione w niniejszym artykule koncentrują się na środkach wspólnotowych, skierowanych do sektora ochrony zdrowia. Liczne badania dowodza, iż stan zdrowia jest uzależniony od wielu czynników, a tym związanym z opieką zdrowotna przypisuje się istotne, ale nie jedyne znaczenie. Różnorodność uwarunkowań stanu zdrowia $i$ ich regionalna specyfika wymaga skoordynowanego podejścia do zdrowia na poziomie 
krajowym i regionalnym, zgodnie z zasada „zdrowie we wszystkich politykach”. Ocena nierówności zdrowia w perspektywie terytorialnej może być podstawa podejmowania decyzji o regionalnym podziale zasobów przyczyniajacych się do zwiększenia inwestycji w szeroko rozumiane determinanty zdrowia [Laskowska, 2013; 2014; Wróblewska, 2012], wykraczających poza inwestycje w sektorze ochrony zdrowia. Przydatne narzędzie ewaluacji polityki zdrowotnej mogą stanowić metody analizy konwergencji.

\section{Literatura}

Bank Danych Lokalnych (a), Główny Urząd Statystyczny, http://stat.gov.pl/bdl, (data wejścia: 20.02.2016).

Bank Danych Lokalnych (b), Główny Urząd Statystyczny, http://stat.gov.pl/bdl/ app/dane_podgrup.display?p_id=373505\&p_token $=0.5969849287066609 \#$ (data wejścia: 20.02.2016).

Bank Danych Lokalnych (c), Główny Urząd Statystyczny, https://bdl.stat.gov.pl/BDL/ dane/podgrup/ tablica (data wejścia: 20.02.2016).

Barro R. J., Sala-I-Martin X., 1991, Convergence across the States and Regions, "Brookings Papers on Economic Activities", no. (1), s. 107-158.

Blas E., Kurup A., 2010, Equity, social determinants and public health programmes, World Health Organization.

Dahlgren G., Whitehead M., 2007, European strategies for tackling social inequities in health: Levelling up, Part 2, World Health Organization.

Departament Fundus:y Europejskich Ministerstwa Zdrowia, http:/ / archiwum.zdrowie.gov.pl/ strona-7-Inne_Fundusze_Programy_Regionalne_Programy_Operacyjne.html (data wejścia: 28.08.2016).

Dubas-Jakóbczyk K., 2014, Rola funduszy strukturalnych Unii Europejskiej w finansowaniu inwestyci w obszarze ochrony zdrowia w Polsce, „Zdrowie Publiczne i Zarządzanie”, t. 12, nr 3, s. 228-238, DOI: doi:10.4467/20842627OZ.14.024.3442.

Gächter M., Theurl E., 2011, Health status convergence at the local level: empirical evidence from Austria, "International Journal for Equity in Health", no. (10),

Geodecki T., 2006, Procesy konwergencji i polaryzacji w regionach Unii Europejskiej, „Zeszyty Naukowe Akademii Ekonomicznej w Krakowie", nr 714.

Goli S., Arokiasamy P., 2014, Trends in health and health inequalities among major states of India: assessing progress through convergence models, "HealthEconomics, Policy and Law", no. (9), s. 143-168, DOI: http://dx.doi.org/10.1017/S1744133113000042.

Health inequalities in the EU - Final report of a consortium, 2013, Consortium lead: Sir Michael Marmot, European Commission Directorate-General for Health and Consumers European Union.

Janssen F., van den Hende A., de Beer J., van Wissen L., 2016, Sigma and beta convergence in regional mortality: A case study of the Netherlands, "Demographic Research", no. (35), DOI: 10.4054/DemRes.2016.35.4.

Kusideł E., 2013, Konwergencja gospodarcza w Polsce i jej znaczenie w osiaganin celów polityki spójności, Wydawnictwo Uniwersytetu Lódzkiego, Łódź. 
Laskowska I., 2012, Zdrowie i nierówności w zdrowiu - determinanty i implikacje ekonomicznospołeczne, Wydawnictwo Uniwersytetu Lódzkiego, Lódź.

Laskowska I., 2013, The Socio-economic Determinants of Health: Results of Empirical Research for Poland, "The International Journal of Health, Wellness, and Society”, vol. 2, Issue 4, Common Ground Publishing LLC Illinois, USA.

Laskowska I., 2014, Nierówności w zdrowiu, [w:] Nierówności społeczne w Polsce, B. Kłos, J. Szymańczak (red.), Wydawnictwo Sejmowe, Warszawa.

Liang D., Zhang D., Huang J., Schweitzer S., 2016, Does Rapid and Sustained Economic Growth Lead to Convergence in Health Resources: The Case of China From 1980 to 2010, "INQUIRY: The Journal of Health Care Organization, Provision, and Financing", no. (53), s. 1-6, DOI: 10.1177/0046958016631699.

Mackenbach J.P., 2013, Convergence and divergence of life expectancy in Europe: a centennial view, "European Journal of Epidemiology”, no. (28), DOI:10.1007/s10654-0129747-x.

Mapa Dotacji UE, www.mapadotacji.gov.pl (data wejścia: 17.11.2015).

Mazurek M., 2010, Fundusze strukturalne jako źródto finansowania inwestycji w jednostkach ochrony zdrowia, „Przegląd Epidemiologiczny”, no. (64).

Policy paper dla ochrony zdrowia na lata 2014-2020. Krajowe ramy strategiczne, 2014, Ministerstwo Zdrowia, Warszawa.

Przestrzenny wymiar nierówności zdrowia i polityka spójności, 2011, S. Golinowska (red.), „Zdrowie Publiczne i Zarządzanie", t. IX, nr 2.

Wróblewska W., 2012, Nierówności społeczne w stanie zdrowia w Polsce-analiza na podstawie samooceny stanu zdrowia orazpoziomu wykesztatcenia, „Roczniki Kolegium Analiz Ekonomicznych", z. 28.

Zarys sytemu ochrony zdrowia. Raport HiT Polska, 2012, S. Golinowska (red.), Narodowy Fundusz Zdrowia, Warszawa.

Zdrowie i ochrona zdrowia w 2013 roku, 2014, Główny Urząd Statystyczny, Warszawa. 